\title{
Plasma fibrinogen and plasminogen levels in health and in ischaemic heart disease
}

\author{
C. M. OGSTON AND D. OGSTON
}

From the Department of Medicine, University of Aberdeen

SYNOPSIS Plasma fibrinogen and plasminogen levels were measured in 122 male and 56 female healthy adult subjects and in 64 men with ischaemic heart disease. Plasma fibrinogen levels were? found to rise markedly and progressively with age in both male and female healthy subjects; plasmin- $\overrightarrow{0}$ ogen showed only a slight rise with age. No sex differences were found for either fibrinogen or plasminogen. The correlation between plasminogen and fibrinogen levels was low, reaching the $5 \% \mathrm{~W}$ level of significance only in men. Patients with ischaemic heart disease were found to have signi- $\circ$ ficantly increased fibrinogen and plasminogen levels in the 31-45 years age group only.

Plasminogen is the inactive precursor of the proteolytic enzyme plasmin which, under physiological circumstances, specifically digests fibrin and thus causes lysis of thrombi or fibrinous exudates. Conversion of plasminogen to plasmin takes place by activators which are widespread in body tissues and present in small amounts in circulating blood. Plasminogen has a close affinity for fibrinogen and fibrin and this affinity forms part of the evidence for the theory of thrombolysis put forward by Sherry, Fletcher, and Alkjaersig (1959) which suggests that the function of plasminogen is to endow fibrin with the capacity for subsequent lysis. They showed that clots of low plasminogen content lyse poorly when exposed to activator.

Because of the possibility that a defect in the fibrinolytic enzyme system has a role in the causation of thrombotic disease we have studied the plasminogen content of plasma in a group of healthy controls and in patients with ischaemic heart disease. In view of the affinity of plasminogen for fibrin and previous reports that fibrinogen levels are elevated in patients with ischaemic heart disease (McDonald and Edgill, 1957; Merskey, Gordon, Lackner, Schrire, Kaplan, Sougin-Mibashan, Nossel, and Moodie, 1960; Pilgeram, 1961; Egeberg, 1962; Katz, McDonald, Davies, and Edgill, 1963) we have also studied the plasma fibrinogen in the same groups and its relationship to plasminogen levels.

\section{METHODS}

Plasma Plasminogen This was assayed by the method of Remmert and Cohen (1949) as modified by Alkjaersig,

Received for publication 17 February 1966,
Fletcher, and Sherry (1959). The results are expressed in Sherry units (the release of $180 \mu \mathrm{g}$. tyrosine in $60 \%$ minutes). The mean difference between duplicates of 50 . samples in the range 3.37 to 5.33 casein units $/ \mathrm{ml}$. was 0.09 casein units $/ \mathrm{ml}$. (standard deviation 0.09 casein units/ml.).

PLASMA FIBRINOGEN This was determined by a modifica-응 tion of the method of Ratnoff and Menzie (1951). Oxalated plasma, $0.25 \mathrm{ml}$., was mixed with $4.5 \mathrm{ml}$. $\overrightarrow{\overrightarrow{0}}$ $0.85 \%$ saline and $0.2 \mathrm{ml}$. thrombin (100 units $/ \mathrm{ml}$.). 3 After standing for 30 minutes the clots were filtered on squares of fibre glass and washed with saline. The clotso were compressed in the fibre glass to remove the fluid:trapped in the fibrin interstices. After further washing the fibrin the fibre glass was dried between cloths. The foldedio fibre glass squares with the enclosed fibrin was boiled? with $2 \mathrm{ml} .0 \cdot 2 \mathrm{~N}$ sodium hydroxide for 10 minutes. When cool, $6 \mathrm{ml} .12 .5 \% \mathrm{w} / \mathrm{v}$ sodium carbonate and $1 \mathrm{ml} .3$ Folin-Ciocalteu's reagent (diluted $1: 2$ ) were added. After 15 minutes the intensity of the colour was read at $670 \mathrm{~m} \mu$. The fibrin content of the clot was read from a standard curve prepared from purified fibrinogen (Kabi Pharmaceuticals Ltd.). All determinations were performed in duplicate.

Blood samples were obtained with the minimum of 0 venous stasis from an ante-cubital vein. Fibrinogen $N$ estimations were performed within two hours of vene- $\sigma$ puncture and the plasminogen assays within 24 hours. It was found that storage of plasma for 48 hours at room temperature did not affect the plasminogen level. Blood was obtained between 9 and 10 a.m. from the majority. of the subjects, and between 2 and 3 p.m. from the remainder.

\section{SUBJECTS}

HEALTHY SUBJECTS These comprised volunteers from number of organizations, students, and members of the? 
medical staff. They were included if they gave no history of chest pain or other history suggestive of atherosclerotic disease, and no recent infection or other illness. In a number of the older subjects an electrocardiogram was carried out to exclude an ischaemic pattern.

ISCHAEMIC HEART DISEASE PATIENTS These were patients who had sustained a transmural myocardial infarction confirmed by electrocardiography and sequential transaminase changes at least three months previously. The majority were receiving therapeutic doses of phenindione or warfarin sodium.

\section{RESULTS}

Table I shows the fibrinogen and plasminogen levels in blood obtained at 9 a.m. and 3 p.m. in five subjects. It can be seen that there is little difference in the levels of fibrinogen or plasminogen between these times. The results obtained from subjects at 3 p.m. have therefore been pooled with those obtained at 9 a.m.

TABLE I

DIURNAL VARIATION IN PLASMA FIBRINOGEN AND PLASMINOGEN

\begin{tabular}{|c|c|c|c|c|}
\hline \multirow[t]{2}{*}{ Subject } & \multicolumn{2}{|l|}{9 A.M. } & \multicolumn{2}{|l|}{3 P.M. } \\
\hline & $\begin{array}{l}\text { Fibrinogen } \\
(\mathrm{mg} . / 100 \mathrm{ml} .)\end{array}$ & $\begin{array}{l}\text { Plasminogen } \\
\text { (casein } \\
\text { units } / m l . \text { ) }\end{array}$ & $\begin{array}{l}\text { Fibrinogen } \\
(\mathrm{mg} . / 100 \mathrm{ml} .)\end{array}$ & $\begin{array}{l}\text { Plasminogen } \\
\text { (casein } \\
\text { units/ml.) }\end{array}$ \\
\hline $\begin{array}{l}1 \\
2 \\
3 \\
4 \\
5\end{array}$ & $\begin{array}{l}260 \\
282 \\
440 \\
290 \\
328\end{array}$ & $\begin{array}{l}4 \cdot 08 \\
3 \cdot 33 \\
4 \cdot 76 \\
4 \cdot 11 \\
3 \cdot 79\end{array}$ & $\begin{array}{l}250 \\
277 \\
465 \\
305 \\
315\end{array}$ & $\begin{array}{l}4 \cdot 11 \\
3 \cdot 33 \\
4 \cdot 92 \\
4 \cdot 11 \\
3 \cdot 82\end{array}$ \\
\hline
\end{tabular}

Figure 1 illustrates the plasminogen levels in two subjects tested on several occasions over a period of 18 and 31 months. The plasminogen levels remained relatively constant over the period studied.

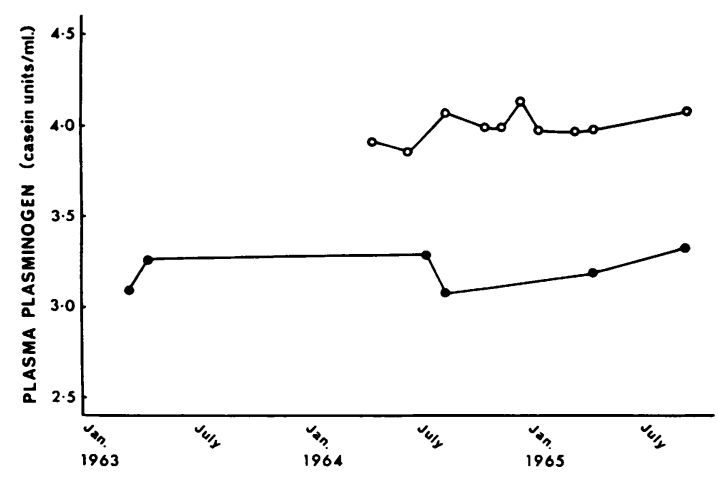

FIG. 1. Serial assays of plasma plasminogen in two healthy subjects.

Table II presents the mean results of the plasminogen assays in healthy men and women divided into age groups, and the individual values are plotted against age in Figures 2 and 3. There was no significant sex difference for plasminogen in any of the age groups studied, but there was a small rise with age in both sexes.

Table III shows the mean fibrinogen levels in men and women in the same age groups. Again the difference between the sexes is not significant in any of the age groups, but there is a marked rise with age in both sexes. Regressions:-

Men, $y=239 \cdot 8+2 \cdot 38 x-0.0005 x^{2}(r=+0.52$, $\mathbf{P}<0.001)$

Women, $\mathrm{y}=283.9+1.64 \mathrm{x}-0.003 \mathrm{x}^{2}(\mathrm{r}=+$ $0.37, \mathrm{P}<0.01$ )

where $\mathrm{y}=$ fibrinogen level in $\mathrm{mg} . / 100 \mathrm{ml}$. and $\mathbf{x}=$ age in years.

The coefficient of correlation between plasminogen and fibrinogen was calculated for males and females

TABLE II

PLASMA PLASMINOGEN LEVELS IN HEALTHY SUBJECTS

\begin{tabular}{|c|c|c|c|c|c|c|c|c|c|}
\hline \multirow[t]{2}{*}{ Age Group } & \multicolumn{4}{|c|}{ Males } & \multicolumn{4}{|c|}{ Females } & \multirow{2}{*}{$\begin{array}{l}\text { Significance } \\
\text { of Difference }\end{array}$} \\
\hline & No. & Mean Age & Mean & S.E. & No. & Mean Age & Mean & S.E. & \\
\hline $\begin{array}{l}16-25 \\
26-35 \\
36-45 \\
46-55 \\
56-65\end{array}$ & $\begin{array}{l}20 \\
27 \\
32 \\
23 \\
20\end{array}$ & $\begin{array}{l}22 \cdot 4 \\
31 \cdot 7 \\
42 \cdot 3 \\
51 \cdot 5 \\
58 \cdot 7\end{array}$ & $\begin{array}{l}4 \cdot 08 \\
4 \cdot 22 \\
4 \cdot 33 \\
4 \cdot 36 \\
4 \cdot 38\end{array}$ & $\begin{array}{l}0.08 \\
0.07 \\
0.06 \\
0.09 \\
0.13\end{array}$ & $\begin{array}{r}7 \\
15 \\
14 \\
6 \\
14\end{array}$ & $\begin{array}{l}22 \cdot 7 \\
30 \cdot 1 \\
40 \cdot 4 \\
50 \cdot 7 \\
61 \cdot 8\end{array}$ & $\begin{array}{l}4 \cdot 17 \\
4 \cdot 04 \\
4 \cdot 38 \\
4 \cdot 54 \\
4 \cdot 50\end{array}$ & $\begin{array}{l}0.17 \\
0.14 \\
0 \cdot 10 \\
0.06 \\
0.13\end{array}$ & $\begin{array}{l}\mathbf{P}>0.1 \\
\mathbf{P}>0.1 \\
\mathbf{P}>0.1 \\
\mathbf{P}>0.1 \\
\mathbf{P}>0.1\end{array}$ \\
\hline
\end{tabular}

TABLE III

PLASMA FIBRINOGEN LEVELS IN HEALTHY SUBJECTS

\begin{tabular}{|c|c|c|c|c|c|c|c|c|c|}
\hline \multirow[t]{2}{*}{ Age Group } & \multicolumn{4}{|c|}{ Males } & \multicolumn{4}{|c|}{ Females } & \multirow{2}{*}{$\begin{array}{l}\text { Significance } \\
\text { of Difference }\end{array}$} \\
\hline & No. & Mean Age & Mean & S.E. & No. & Mean Age & Mean & S.E. & \\
\hline $\begin{array}{l}16-25 \\
26-35 \\
36-45 \\
46-55 \\
56-65\end{array}$ & $\begin{array}{l}20 \\
27 \\
32 \\
23 \\
20\end{array}$ & $\begin{array}{l}22 \cdot 4 \\
31 \cdot 7 \\
42 \cdot 3 \\
51 \cdot 5 \\
58 \cdot 7\end{array}$ & $\begin{array}{l}296 \\
309 \\
331 \\
360 \\
384\end{array}$ & $\begin{array}{r}9 \\
6 \\
8 \\
10 \\
15\end{array}$ & $\begin{array}{r}7 \\
15 \\
14 \\
6 \\
14\end{array}$ & $\begin{array}{l}22 \cdot 7 \\
30 \cdot 1 \\
40 \cdot 4 \\
50 \cdot 7 \\
61 \cdot 8\end{array}$ & $\begin{array}{l}325 \\
322 \\
341 \\
392 \\
371\end{array}$ & $\begin{array}{l}12 \\
11 \\
14 \\
25 \\
11\end{array}$ & $\begin{array}{l}\mathbf{P}>0.1 \\
\mathbf{P}>0.1 \\
\mathbf{P}>0.1 \\
P>0.1 \\
P>0.1\end{array}$ \\
\hline
\end{tabular}




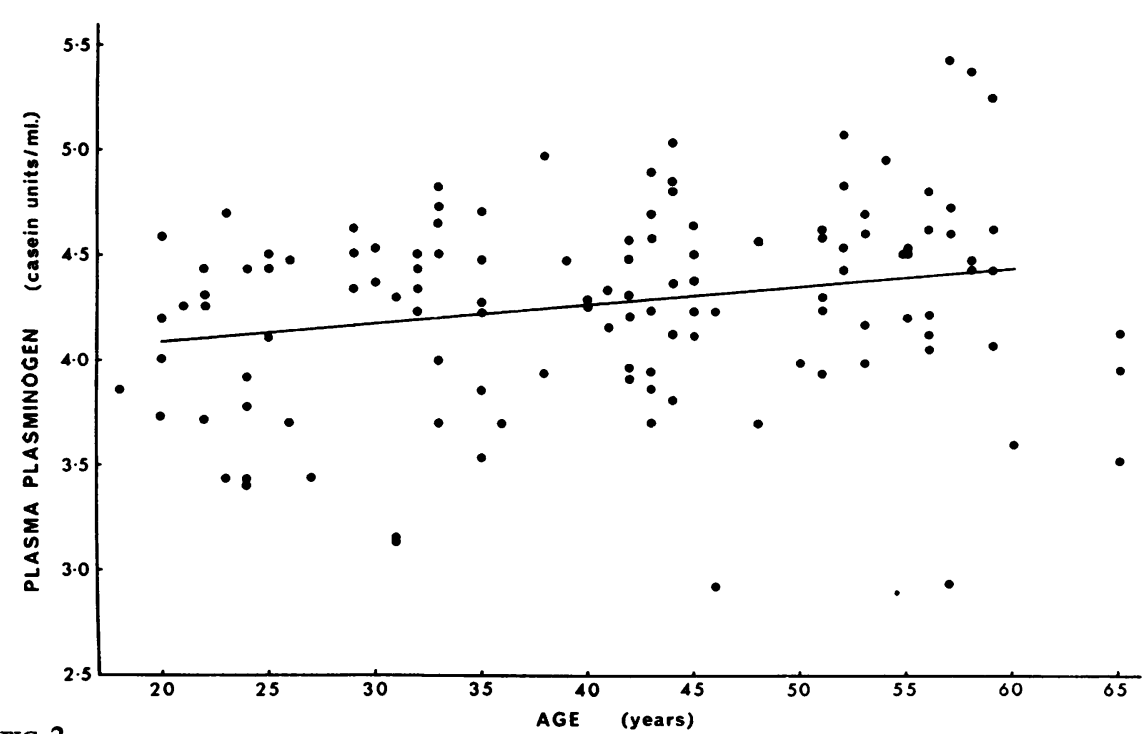

FIG. 2. Plasma plasminogen levels of healthy men plotted against age. Regression: $y=3 \cdot 89+0 \cdot 010 x-$ $0.000011 x^{2} ; r=+$ $0 \cdot 25, P<0 \cdot 01$.

FIG 2 .

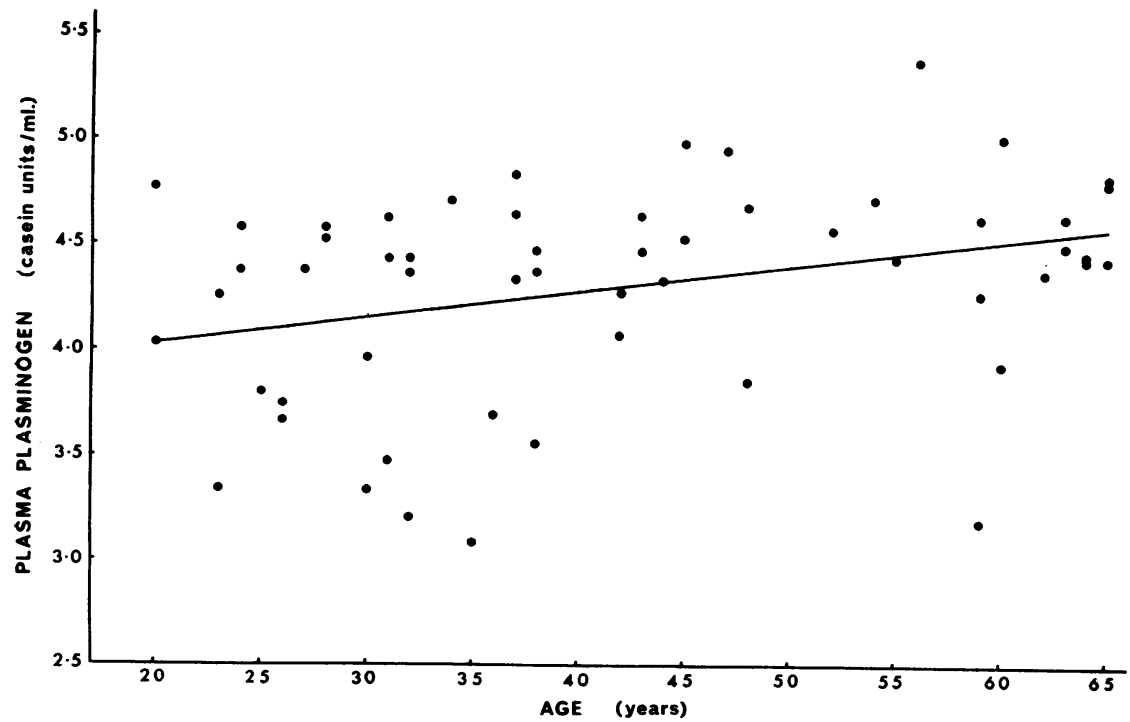

FIG. 3. Plasma plasminogen levels of healthy women plotted against age. Regression: $y=3 \cdot 82+0.0114 x$ $+0.0000082 x^{2} ; r=\frac{8}{0}$ $+0.34, P<0.05$.

separately. For males the correlation was just significant $(r=+0.20, p<0.05)$, but failed to reach the $5 \%$ significance level for women $(r=+0 \cdot 16, p>$ $\mathbf{0} \cdot \mathbf{1})$.

The plasma fibrinogen level has been found to be unaffected by therapeutic doses of phenindione (Merskey et al., 1960; Eastham and Morgan, 1963) or by warfarin sodium (Nakamura, Kunitake,
TABLE IV

EFFECT OF ORAL WARFARIN SODIUM THERAPY ON PLASMA FIBRINOGEN AND PLASMINOGEN (MEANS OF FIVE PATIENTS)

Before Therapy Three to Four Months after
Start of Therapy

Fibrinogen

(mg./100 ml.)

Plasminogen

415

404

4.38

$4 \cdot 36$ 
TABLE V

COMPARISON BETWEEN PLASMA PLASMINOGEN LEVELS IN HEALTHY SUBJECTS AND IN PATIENTS WITH ISCHAEMIC HEART DISEASE

\begin{tabular}{|c|c|c|c|c|c|c|c|c|c|}
\hline \multirow[t]{2}{*}{ Age Group } & \multicolumn{4}{|c|}{ Healthy Subjects } & \multicolumn{4}{|c|}{ Ischaemic Heart Disease Patients } & \multirow{2}{*}{$\begin{array}{l}\text { Significance } \\
\text { of Difference }\end{array}$} \\
\hline & No. & Mean Age & Mean & S.E. & No. & Mean Age & Mean & S.E. & \\
\hline $\begin{array}{l}31-45 \\
46-55 \\
56-65\end{array}$ & $\begin{array}{l}51 \\
23 \\
20\end{array}$ & $\begin{array}{l}38 \cdot 9 \\
51 \cdot 5 \\
58 \cdot 7\end{array}$ & $\begin{array}{l}4 \cdot 28 \\
4 \cdot 36 \\
4 \cdot 38\end{array}$ & $\begin{array}{l}0.06 \\
0.09 \\
0.13\end{array}$ & $\begin{array}{r}9 \\
26 \\
29\end{array}$ & $\begin{array}{l}37 \cdot 9 \\
51 \cdot 6 \\
61 \cdot 0\end{array}$ & $\begin{array}{l}4 \cdot 76 \\
4 \cdot 39 \\
4 \cdot 35\end{array}$ & $\begin{array}{l}0.16 \\
0.07 \\
0.03\end{array}$ & $\begin{array}{l}\mathbf{P}<0.01 \\
\mathbf{P}>0.1 \\
\mathbf{P}>0.1\end{array}$ \\
\hline
\end{tabular}

TABLE VI

COMPARISON BETWEEN PLASMA FIBRINOGEN LEVELS IN HEALTHY SUBJECTS AND IN PATIENTS WITH ISCHAEMIC HEART DISEASE

\begin{tabular}{|c|c|c|c|c|c|c|c|c|c|}
\hline \multirow[t]{2}{*}{ Age Group } & \multicolumn{4}{|c|}{ Healthy Subjects } & \multicolumn{4}{|c|}{ Ischaemic Heart Disease Patients } & \multirow{2}{*}{$\begin{array}{l}\text { Significance } \\
\text { of Difference }\end{array}$} \\
\hline & No. & Mean Age & Mean & S.E. & No. & Mean Age & Mean & S.E. & \\
\hline $\begin{array}{l}31-45 \\
46-55 \\
56-65\end{array}$ & $\begin{array}{l}51 \\
23 \\
20\end{array}$ & $\begin{array}{l}38 \cdot 9 \\
51 \cdot 5 \\
58 \cdot 7\end{array}$ & $\begin{array}{l}324 \\
360 \\
384\end{array}$ & $\begin{array}{r}6 \\
10 \\
15\end{array}$ & $\begin{array}{r}9 \\
26 \\
29\end{array}$ & $\begin{array}{l}37 \cdot 9 \\
51 \cdot 6 \\
61 \cdot 0\end{array}$ & $\begin{array}{l}363 \\
365 \\
379\end{array}$ & $\begin{array}{l}12 \\
13 \\
12\end{array}$ & $\begin{array}{l}\mathbf{P}<0.02 \\
\mathbf{P}>0.1 \\
\mathbf{P}>0.1\end{array}$ \\
\hline
\end{tabular}

Fujita, and Reilly, 1964). Table IV presents the mean levels of plasminogen and fibrinogen before and after three to four months of treatment with therapeutic doses of warfarin sodium in five subjects. These results confirm that oral anticoagulants do not affect fibrinogen levels and show that plasminogen levels are not altered by such therapy.

Table $\mathrm{V}$ compares the plasminogen levels in healthy male subjects with those in male patients with ischaemic heart disease. The ischaemic heart disease patients have a significantly higher plasminogen level only in the age group 31-45 years.

Table VI compares the fibrinogen levels in the two groups. Again it is only the younger ischaemic heart disease patients who have a significantly higher fibrinogen level than healthy controls of a similar age.

\section{DISCUSSION}

There have been few studies of plasminogen levels in health. Jacobsen (1964) and Hedner and Nilsson (1965) found no significant age or sex differences in plasminogen level, but the number of subjects studied was relatively small. We have also found no sex difference in plasminogen levels, but have found a small rise with age in healthy subjects over the age range 20 to 65 years. Ischaemic heart disease patients had plasminogen levels which did not differ significantly from age-matched controls apart from the small group of patients under the age of 45 who had a significantly increased plasma plasminogen. There is no evidence, therefore, that plasminogen deficiency is important in the causation of thrombotic disease.

Studies of the changes in fibrinogen concentration with age have produced general agreement that concentrations rise with increasing age (Schulz, 1955; Pilgeram, 1961) and our results confirm this. There is disagreement, however, on sex differences in plasma fibrinogen concentration. Hume (1961) concluded that there was no increase in adult women until after the 40-65 years age group whereas there was a progressive rise in men throughout adult life. We have found that both men and women have a progressive rise in fibrinogen with age without a significant sex difference in any age group. There was no particular increase in the post-menopausal years.

Several investigators have reported that fibrinogen levels are raised in patients with ischaemic heart disease (Merskey et al., 1960; Pilgeram, 1961), but there is not complete agreement (Naimi, Goldstein, and Proger, 1963). Katz et al. (1963) studied younger patients with ischaemic heart disease and found them to have significantly higher fibrinogen levels than age-matched controls. In the present study a significantly increased plasma fibrinogen level was found only in younger patients with ischaemic heart disease.

Although clots made from plasma with a high concentration of fibrinogen are more resistant to lysis than those made at a lower concentration there is no information to indicate whether this applies to thrombi in vivo. The role of a raised plasma fibrinogen level in the causation of thrombotic disease is therefore not known. Our results would suggest that the fibrinogen concentration in blood is of little importance in the production of thrombotic complications of atheroma, but the finding of raised fibrinogen levels in young ischaemic heart disease patients leaves this possibility sub judice. 
We are indebted to the volunteers from the Aberdeen City Police, the staff of the Clydesdale Bank Ltd., and the Electrical Association for Women for their cooperation. Our thanks are due to Professor H. W. Fullerton for his help and his advice in the preparation of this paper.

This study was supported by the Tobacco Research Council on the recommendation of the British Heart Foundation.

\section{REFERENCES}

\author{
Alkjaersig, N., Fletcher, A. P., and Sherry, S. (1959). J. clin. Invest.,
38, 1086. \\ Eastham, R. D., and Morgan, E. H. (1963). Lancet, 2, 1196. \\ Egeberg, O. (1962). Scand. J. clin. Lab. Invest., 14, 253.
}

Hedner, U., and Nilsson, I. M. (1965). Thrombos., Diathes. haemorrh (Stuttg.), 14, 545.

Hume, R. (1961). J. clin. Path., 14, 167.

Jacobsen, C. D. (1964). Scand. J. clin. Lab. Invest., 16, 372.
Katz, A. M., McDonald, L., Davies, B., and Edgill, M. (1963) Lancet, 1, 801.

McDonald, L., and Edgill, M. (1957). Lancet, 2, 457.

Merskey, C., Gordon, H., Lackner, H., Schrire, V., Kaplan, B. J.ð Sougin-Mibashan, R., Nossel, H. L., and Moodie, A. (1960) Brit. med. J., 1, 219.

Naimi, S., Goldstein, R., and Proger, S. (1963). Circulation, 27, 904. Nakamura, R. M., Kunitake, G. M., Fujita, K., and Reilly, E. B (1964). Lancet, $2,821$.

Pilgeram, L. O. (1961). J. appl. Physiol., 16, 660.

Ratnoff, O. D., and Menzie, C. (1951). J. Lab. clin. Med., 37, 316. $\vec{O}$

Remmert, L. F., and Cohen, P. P. (1949). J. biol. Chem., 181, 431-

Schulz, F. H. (1955). In Thrombosis and Embolism. Proceedings of the I International Conference, Basle, 1954, edited by T. Kollerg and W. R. Merz, p. 463. Schwabe, Basle.

Sherry, S., Fletcher, A. P., and Alkjaersig, N. (1959). Physiol. Rev. 39, 343.

\section{The May 1966 Issue}

\section{THE MAY 1966 ISSUE CONTAINS THE FOLLOWING PAPERS}

What pathology-and pathology for what? GEORGE J. CUNNINGHAM

Marrow dysplasia with $\mathrm{C}$ trisomy and anomalies of the granulocyte nuclei SYLVIA D. LAWLER, H. E. M. KAY, and M. S. C. BIRBECK

Changes in serum enzyme levels accompanying cardiac surgery with extracorporeal circulation NORA WELBOURN, D. G. MELROSE, and D. W. MOSS

Method of estimating the inhibitory effect of plasma or serum upon urokinase-activated fibrinolysis R. D. MANN

Fibrinolytic activity in blood and urine C. A. C. CHARLTON

Studies on the fibrinolytic enzyme system in obesity N. B. BENNETT, C. M. OGSTON, G. M. MCANDREW, and D. OGSTON

Importance of cardiomyopathy and cerebral ischaemia in the diagnosis of fatal coma in pregnancy RICHARD C. R. CONNOR and J. HUME ADAMS

Alpha-hydroxybutyrate dehydrogenase activity in sexlinked muscular dystrophy H. A. JOHNSTON, J. H. WILKINSON, WENDY A. WITHYCOMBE, and S. RAYMOND

Ribonucleic acid content of Burkitt tumour cells D. H. WRIGHT and J. C. MCALPINE

Morphology and functional cytology of the small intestinal mucosa in malabsorptive disorders and other diseases LIONEL FRY and R. M. H. MCMINN
Hodgkin's granuloma complicated by generalize cytomegalic inclusion disease and gastrointestina moniliasis MICHAEL S. ROSE

Multiple myeloma in Jamaica: A study of 40 cases with special reference to the incidence and laboratory diagnosis H. MCFARLANE

Pedunculated islet-cell tumour of the duodenum R. P. BRITT

Comparative immunological studies in liver diseasesิ GYÖRGY SZÉCSEY, GYÖRGY DÓBIÁS, and ERNÖ KEREKES

Granulocyte changes in infectious mononucleosis R. L CARTER

Assessment of hypothelamic pituitary function in endocrine disease F. C. GREENWOOD and J. LANDON

Micro methods and micro apparatus for chemica? pathology with special reference to paediatrics BARBARAn

E. CLAYTON and P. JENKINS

\section{Technical methods}

Simultaneous demonstration of mast cells and plasma cells DIANA BOWER and C. G. CHADWIN

Note on preserving a standard suspension of live vibriosD H. K. GHOSH, W. H. R. LUMSDEN, and GILLIAN J. C. HARDY?

Letter to the Editor K. G. GADD

Book reviews

Copies are still available and may be obtained from the PUBLISHING MANAGER, BRITISH MEDICAL ASSOCIATION, TAVISTOCK SQUARE, W.C.1. price 18s. 6D. 